\title{
Pancreatic secretory trypsin inhibitor in gastrointestinal mucosa and gastric juice
}

\author{
T C Freeman, R J Playford, C Quinn, K Beardshall, L Poulter, J Young, J Calam
}

\begin{abstract}
We studied the distribution of pancreatic secretory trypsin inhibitor (PSTI) in the epithelia of the gastrointestinal tract and determined whether PSTI is secreted into gastric juice. PSTI was measured by a specific radioimmunoassay in biopsy specimens taken from the upper $(n=8)$ and lower $(n=7)$ gastrointestinal tract of patients with normal endoscopies. PSTI was present in the stomach, small intestine, and colon. Concentrations ( $\mu \mathrm{g} / \mathrm{g}$ protein) were highest in the stomach, and significantly higher in the antrum (1240, 670-1700, median and range) than in the gastric body $(370,350-570)(p<0.01)$. Concentrations were similar in the duodenum $(180$, 80-210) and colon (160, 130-360). PSTI determined by immunohistochemistry was present in mucus secreting gastric foveolar cells, duodenal Paneth cells, and colonic non mucus cells. PSTI was present in gastric juice. The median (range) concentration of PSTI in basal gastric juice from 13 patients with duodenal ulcers was 9 (3-21) $\mu \mathrm{g} / \mathrm{l}$ and did not change during stimulation with pentagastrin. The rate of secretion, however, did increase significantly $(\mathrm{p}<0.05)$ from $1430(180-2810) \mathrm{ng} / \mathrm{h}$ to 4500 (1250-12770) $\mathrm{ng} / \mathrm{h}$ during pentagastrin stimulation. PSTI was labile in acid pepsin but stable in the neutral conditions present in the mucus layer. The presence of pancreatic secretory trypsin inhibitor throughout the gut and its secretion into the lumen suggests a hitherto unrecognised mechanism protecting gastrointestinal epithelia against luminal proteases.
\end{abstract}

Pancreatic secretory trypsin inhibitor (PSTI) is a small protein containing 56 amino acid residues which was originally isolated from bovine pancreas, ${ }^{1}$ and human PSTI has now been purified ${ }^{2-4}$ and cloned. ${ }^{5}$ PSTI is thought to protect the pancreas from prematurely activated proteases but the recent demonstration of PSTI-like immunoreactivity (PSTI-LI) in other regions of the gut $^{6-8}$ and its isolation from the human stomach,' suggests that PSTI may protect the whole gastrointestinal tract.

The present study was undertaken to determine epithelial concentrations of PSTI using biopsy specimens obtained from the stomach, small intestine, and colon and to study the cellular distribution of PSTI-LI. We also analysed gastric juice to determine whether PSTI is secreted into the lumen.

Methods

The local ethics committee approved the proto- col and all patients gave informed consent.

All chemicals were purchased from BDH (Poole, Dorset) unless otherwise stated.

PURIFICATION AND RADIOIMMUNOASSAY OF PSTI Pancreatic juice from postoperative pancreatic drains was stored at $-20^{\circ} \mathrm{C}$ until extraction. Purification of PSTI was based on the method of Iwai et al. ${ }^{10}$ Briefly, pooled juice was mixed with an equal volume of $0.1 \mathrm{M}$ sodium citrate, and the $\mathrm{pH}$ adjusted to $2 \cdot 5$. Sodium chloride was then added to a final concentration of $1 \mathrm{M}$ and the mixture maintained at $80^{\circ} \mathrm{C}$ for 40 minutes, centrifuged at $3500 \mathrm{~g}$ for 45 minutes at $4^{\circ} \mathrm{C}$, and the supernatant concentrated on a C-18 Sep-Pak cartridge (Waters Associates, Milford MA) equilibrated with $0.05 \% \mathrm{v} / \mathrm{v}$ trifluoroacetic acid in water. The cartridge was then eluted with $80 \%$ acetonitrile in $0.05 \%$ trifluoroacetic acid, and the eluent lyophilised. The eluent was reconstituted in $0.05 \mathrm{M}$ sodium bicarbonate and applied to a $1.5 \times 100 \mathrm{~cm}$ column packed with Sephadex G-50 superfine (Pharmacia, Uppsala, Sweden) and eluted with the same buffer. Fractions containing trypsin inhibitor activity were pooled, lyophilised, and further purified by reverse phase high pressure liquid chromatography on a $10 \times 100 \mathrm{~mm}$ Dynamax C-8 column (12 $\mu \mathrm{m}, 300$ $\AA$, Rainin, Woburn MA), eluted with a gradient of $16-30 \%$ acetonitrile in $0.1 \%$ trifluoroacetic acid. PSTI eluted in a number of fractions as several poorly resolved peaks and a mixture of these fractions was used for immunisation of rabbits. A sample was also applied to a Mono $S$ column (Pharmacia) equilibrated with ammonium acetate $0.1 \mathrm{M}, \mathrm{pH} 3.5$ and eluted with a gradient of ammonium acetate $0 \cdot 1 \mathrm{M}, \mathrm{pH}$ 3.5-4.5 (Fig 1). When the three peaks of trypsin inhibitor that eluted from the Mono $S$ column were rerun on a $4.6 \times 250 \mathrm{~mm}$ Dynamax C-8 reverse phase high pressure liquid chromatography column $(12 \mu \mathrm{m}, 150 \AA)$ eluted with a gradient from $22-30 \%$ acetonitrile in $0 \cdot 1 \%$ trifluoroacetic acid, peaks I and III emerged as single peaks whereas peak II separated into 2 peaks $-\mathrm{II}_{1}$ and $\mathrm{II}_{2}$. The molecular masses of the four peaks were determined by a ZAB-SE mass spectrometer (VG Instruments, Altrincham, Cheshire) and the amino acid sequence of peak 1 was analysed by a protein sequencer (Model 470, Applied Biosystems, Foster City, California).

Four New Zealand white rabbits were immunised initially with $60 \mu \mathrm{g}$ PSTI in $0.5 \mathrm{ml}$ Freund's complete adjuvant (Sigma, Gillingham, Dorset) and subsequently boosted with $30 \mu \mathrm{g}$ PSTI in $0.5 \mathrm{ml}$ Freund's incomplete adjuvant at four weekly intervals. One produced antiserum $\mathrm{T} 4$.

Human PSTI (peak III) was radioiodinated and Bioscience, ICI Macclesfield, Cheshire J Young

Correspondence to:

Accepted for publication

16 January 1990

Gastroenterology Unit,
Department of Medicine,
Royal Postgraduate
Medical School, Du Cane
Road, London W12 0NN
T C Freeman
R J Playford
C Quinn
K Beardshall
J Calam
Biotechnology
L Poulter
and Bioscience, ICI
Pharmaceuticals,
Macclesfield, Cheshire
J Young
Correspondence to:
Dr John Calam.
Accepted for publication
16 January 1990




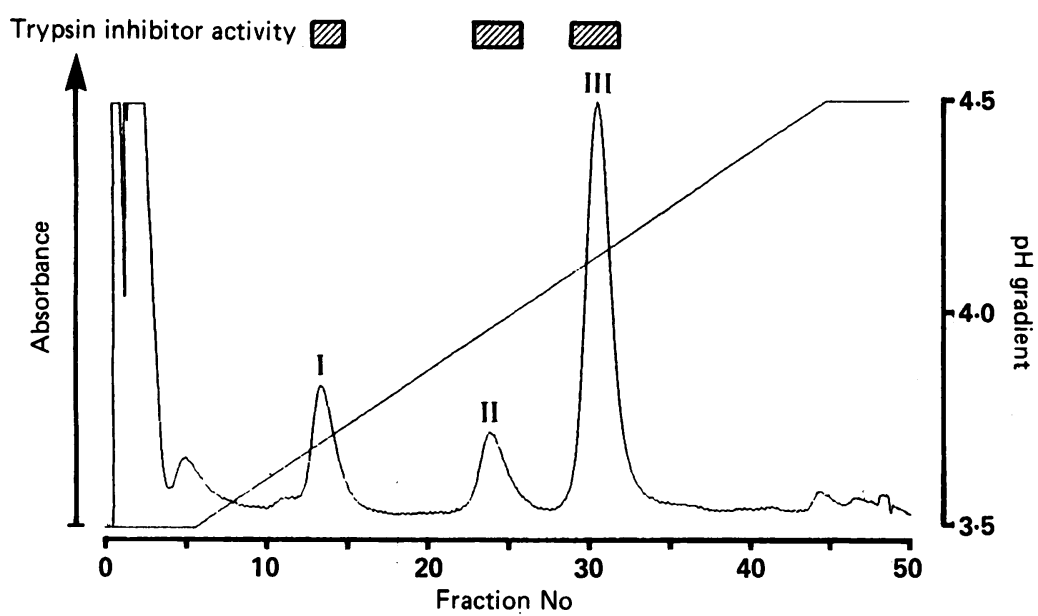

Figure 1: Elution profile of pancreatic secretory trypsin inhibitor (PSTI) extracted from human pancreatic juice from a Pharmacia Mono S column, equilibrated with ammonium acetate $(0 \cdot 1 \mathrm{M}$, pH 3.5) and eluted with a gradient run from $\mathrm{pH} 3.5$ to 4.5. Elution of the PSTI from the column was observed as optical density at 280 nm and trypsin inhibitor activity.

with ${ }^{125} \mathrm{I}$ by the chloramine $\mathrm{T}$ method"1 ${ }^{11}$ and tracer, $1500 \mathrm{cpm} /$ tube, was incubated with antiserum T4 (final dilution 1:500 000) together with PSTI standards $(0.01-50 \mathrm{ng} / \mathrm{ml})$ or samples in $1 \mathrm{ml}$ of sodium phosphate buffer $(0.5 \mathrm{M}, \mathrm{pH} 7.3)$ containing $0 \cdot 15 \%$ bovine serum albumin (Sigma) and $0.02 \%$ sodium azide. Incubation was at $4^{\circ} \mathrm{C}$ for 3 days and separation was achieved by adding to each tube at $4^{\circ} \mathrm{C}, 100 \mu \mathrm{l}$ of ethylenediamine

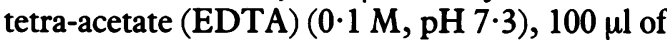
$2 \%$ rabbit serum in assay buffer, $100 \mu l$ of second antibody (goat antirabbit antiserum, type R 0881, Sigma) diluted 1:5 in assay buffer, and $700 \mu \mathrm{l}$ of $6 \%$ polyethylene glycol 6000 in albumin free assay buffer. The tubes were mixed and incubated at $4^{\circ} \mathrm{C}$ for 40 minutes before being centrifuged at $3500 \mathrm{~g}$ and $4^{\circ} \mathrm{C}$ for 15 minutes. The supernatant was aspirated into separate tubes and both tubes counted.

\section{COLLECTION AND EXTRACTION OF ENDOSCOPIC BIOPSY SPECIMENS}

Upper gastrointestinal biopsy specimens were collected during routine endoscopy, using FB25K forceps (Keymed, Southend-on-Sea, Essex), from eight patients, three men and five women, mean age 46 years (range 32-61 years). These patients were under investigation for dyspepsia, but endoscopy and other investigations proved normal and the final diagnosis was non-ulcer dyspepsia. Paired endoscopic biopsy specimens were normal on histological examination. No patients took any drugs within two days of the examination. The mean (SD) weight of the biopsy specimens was $6 \cdot 8(2 \cdot 0) \mathrm{mg}$.

Lower gastrointestinal biopsy specimens were collected during routine endoscopy, using FG15L forceps (Keymed), from seven patients, four men and three women, mean age 47 years (range 26-65 years). These patients were under investigation for abdominal pain or disturbance of bowel habit, but endoscopy and other investigations showed no abnormality and the final diagnosis was the irritable bowel syndrome. Paired endoscopic biopsy specimens were normal on histological examination. None of the patients took any drugs during the two days before examination except for a bowel preparation, which comprised a low residue diet, two sachets of Picolax (Ferring, Feltham, Middx), and plentiful fluids. The mean (SD) weight of biopsy specimens was $10.6(3.0) \mathrm{mg}$.

Biopsy specimens were immediately frozen in liquid nitrogen where they remained until extraction. They were extracted on ice by homogenisation in $200 \mu \mathrm{l}$ of Tris buffer $(10 \mathrm{mM}, \mathrm{pH}$ 7.3) for 1 minute. Extracts were centrifuged at $15850 \mathrm{~g}$ for 1 minute and supernatants frozen on solid $\mathrm{CO}_{2}$ and stored at $-20^{\circ} \mathrm{C}$ before radioimmunoassay for PSTI and measurement of protein concentration by a modification of Lowry's method. ${ }^{12}$

\section{GASTRIC JUICE}

Gastric juice was collected during routine pentagastrin tests on 18 patients, 13 men and five women, in whom duodenal ulcers had been seen at endoscopy within seven days of study. Their mean age was 49 years (range 25-77 years). None took any drugs in the two days before the study.

Gastric juice was collected from the last of three 10 minute basal collections and after stimulation with pentagastrin $0.6 \mu \mathrm{g} / \mathrm{kg}$ per hour for at least 80 minutes. Juice $(2 \mathrm{ml})$ was collected directly from the aspiration tube, and immediately neutralised by mixing with $3 \mathrm{ml}$ $0.17 \mathrm{M}$ sodium bicarbonate on ice. Samples were then frozen at $-20^{\circ} \mathrm{C}$ before assay.

Gastric juice samples were analysed for bilirubin with a RA-1000 analyser (Technical Instrument Corporation), using Technicon method number SM-0179887. Tryptic activity was determined by the $\mathrm{pH}$ stat method using $\mathrm{N \alpha}$ p-tosyl-L-arginine methyl ester (Sigma) as substrate. ${ }^{13}$

CHROMATOGRAPHY OF GASTROINTESTINAL PSTI PSTI-LI in gastric juice and extracts of biopsy specimens taken from the colon and gastric antrum were analysed by reversed phase high pressure liquid chromatography on a $4.6 \times$ $250 \mathrm{~mm}, \mathrm{C}-8$ Dynamax column $(12 \mu \mathrm{m}, 150 \AA$, Rainin), eluted with a gradient of $16-30 \%$ acetonitrile in $0.1 \%$ triflouroacetic acid. Eluates were lyophilised before radioimmunoassay. The system had been previously calibrated with pancreatic PSTI.

\section{STUDIES OF THE STABILITY OF PSTI IN GASTRIC} JUICE

Pentagastrin stimulated gastric juice was obtained from two subjects with duodenal ulcers. Tris- $\mathrm{HCl}$ was added to a final concentration of $10 \mathrm{mM}$, to stabilise the $\mathrm{pH}$ during the study. Portions $(10 \mathrm{ml})$ of each juice were adjusted to $\mathrm{pH} 2 \cdot 0, \mathrm{pH} 4 \cdot 0, \mathrm{pH} 6 \cdot 0$, and $\mathrm{pH} 7 \cdot 4$ by the addition of $\mathrm{NaOH}$. Pure human PSTI was then incubated with each portion at an initial concentration of $60 \mathrm{ng} / \mathrm{ml}$ at $37^{\circ} \mathrm{C}$. At the times shown in Figure 4, $250 \mu \mathrm{l}$ samples were removed, immediately neutralised by addition of an equal volume of $0.17 \mathrm{M}$ sodium bicarbonate, frozen on solid $\mathrm{CO}_{2}$, and stored at $-20^{\circ} \mathrm{C}$ until radioimmunoassay. In control studies PSTI was incubated as already described, but in Tris- $\mathrm{HCl}$ buffer at $\mathrm{pH} 2 \cdot 0$ and $4 \cdot 0$.

The stability of PSTI in unbuffered gastric 
Figure 2: The inhibition of binding of pancreatic secretory trypsin inhibitor (PSTI) tracer to antiserum T4 by human PSTI and other substances.

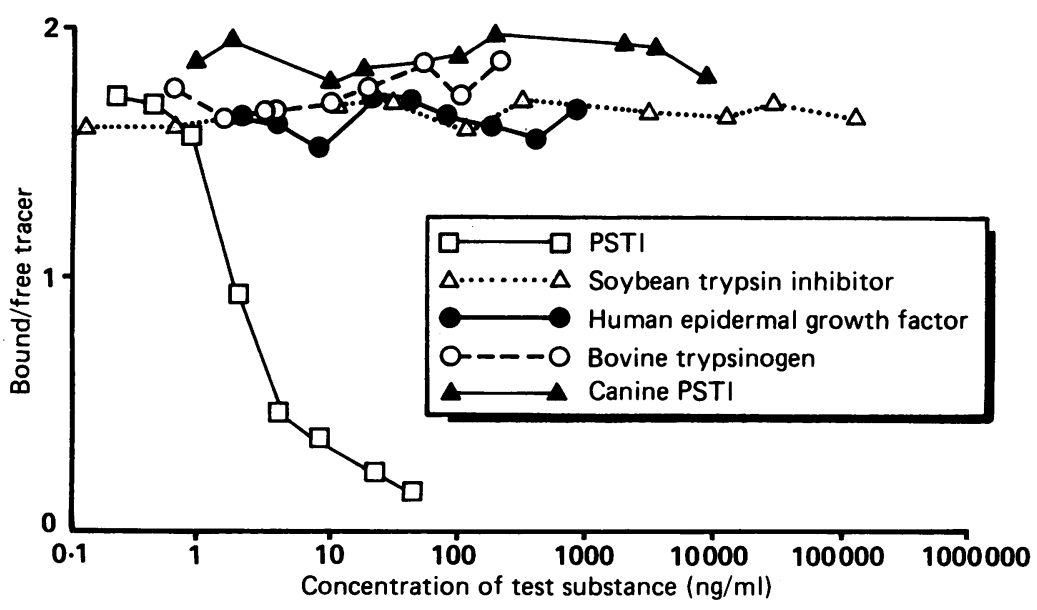

For statistical analysis Wilcoxon's rank sum test was used and results are expressed as median and range; $p<0.05$ was taken to be statistically significant.

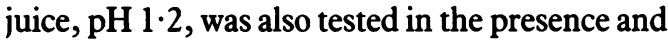
absence of pepstatin (Sigma) $200 \mu \mathrm{g} / \mathrm{ml}$ with incubation for 1 hour at $37^{\circ} \mathrm{C}$.

CONCENTRATION OF PSTI IN PANCREATIC JUICE Pancreatic juice was collected from postoperative pancreatic drains from three patients (one man, two women), two of whom had undergone pancreatic surgery for pancreatic tumours and one of whom had chronic pancreatitis. The juice was frozen and stored at $-20^{\circ} \mathrm{C}$ until the concentration of PSTI was determined by radioimmunoassay.

\section{IMMUNOHISTOCHEMISTRY}

Sections $2 \mu \mathrm{m}$ thick were cut from samples of normal oesophagus, stomach, and small and large intestine. Immunoperoxidase staining was performed using a routine peroxidaseantiperoxidase procedure. ${ }^{14}$ Briefly, sections were dewaxed, rehydrated, and trypsinised at $37^{\circ} \mathrm{C}$ for 10 minutes to unmask antigenic sites..$^{15}$ Endogenous peroxidase was blocked using methanolic hydrogen peroxide for 30 minutes, and the sections rinsed in phosphate buffered saline and incubated with normal swine serum (Dako Ltd, High Wycombe, Bucks) for 15 minutes. They were then incubated with the primary antibody, $\mathrm{T} 4$, overnight at $4^{\circ} \mathrm{C}$, rinsed, and incubated with swine antirabbit immunoglobulin (Dako) for 30 minutes at room temperature. After rinsing in phosphate buffered saline the sections were incubated with peroxidaseantiperoxidase complex (Dako) for 30 minutes at the recommended dilution and rinsed again. The sections were then developed with $3,3^{\prime}$ diaminobenzidine tetrahydrochloride (Aldrich Ltd, Gillingham, Dorset) for 5 minutes and then counterstained lightly with haematoxylin. Finally, the sections were dehydrated and mounted using pertex (Histolab and Cytolab, Hemel Hempstead, Herts). Negative controls were obtained by substituting normal rabbit serum for the PSTI specific antiserum.

\section{Results}

PURIFICATION AND RADIOIMMUNOASSAY OF PSTI The molecular masses of the four peaks, as determined by mass spectrometry, were I: $6242 \cdot 5, \mathrm{II}_{1}: 6241 \cdot 8, \mathrm{II}_{2}: 6241 \cdot 6$, and III: $6242 \cdot 5$, compared with the predicted molecular mass for protonated PSTI of $6242 \cdot 1$. Amino acid sequence analysis of peak I showed that the $\mathrm{N}$ terminal tridecapeptide sequence of peak I was equal to that of human PSTI.

The interassay and intra-assay variabilities of the radioimmunoassay were $17 \%$ and $8 \%$ respectively. The detection limit of the assay was $0.05 \mathrm{ng} /$ tube. The binding of tracer to antibody was not inhibited by bovine trypsinogen (Sigma), human epidermal growth factor (donated by $\mathbf{H}$ Gregory), soybean trypsin inhibitor (Sigma), or canine PSTI (purified by author) (Fig 2). The ratios of cross reactivity of the different forms to peak III were I: $0 \cdot 70: 1$, II: 0.86:1.

\section{CONCENTRATIONS OF PSTI-LI IN ENDOSCOPIC} BIOPSY SPECIMENS

The concentrations of PSTI-LI in biopsy specimens taken from different regions of the human gastrointestinal tract, expressed as $\mu \mathrm{g} / \mathrm{g}$ wet weight and $\mu \mathrm{g} / \mathrm{g}$ protein in extracts, are shown in Table I. PSTI-LI was undetectable in specimens from the oesophagus, but the stomach contained the most PSTI-LI, the concentration being significantly greater in the antrum than in the body of the stomach $(p<0.01)$. Concentrations of PSTI-LI were similar in the duodenum and colon. There was no significant difference between mucosal concentrations of PSTI-LI in the first and second parts of the duodenum, or between the regions of the colon. The median (range) concentration for each patient was 180 $(80-210) \mu \mathrm{g} / \mathrm{g}$ protein in the duodenum and 160 $(130-360) \mu \mathrm{g} / \mathrm{g}$ protein in the colon.

\section{SECRETION AND STABILITY OF PSTI-LI IN}

GASTRIC JUICE

Trypsin was not detected in any sample of gastric juice. One sample which contained bilirubin was excluded from analysis. PSTI-LI was, detected in gastric juice from all patients. The concentration

TABLE I Tissue concentrations of pancreatic secretory trypsin inhibitor-like immunoreactivity in biopsy specimens taken from the upper $(n=8)$ and lower $(n=7)$ gastrointestinal tract

\begin{tabular}{|c|c|c|c|c|}
\hline \multirow[b]{2}{*}{ Region } & \multicolumn{2}{|c|}{$\begin{array}{l}\text { PSTI-LI/wet weight } \\
(\mu g / g)\end{array}$} & \multicolumn{2}{|c|}{$\begin{array}{l}\text { PSTI-LI/protein } \\
(\mu g / g)\end{array}$} \\
\hline & Median & Range & Median & Range \\
\hline $\begin{array}{l}\text { Oesophagus } \\
\text { Stomach: }\end{array}$ & $<0.1$ & All $<0 \cdot 1$ & & \\
\hline $\begin{array}{l}\text { Body } \\
\text { Antrum }\end{array}$ & $\begin{array}{l}19 \cdot 9 \\
38 \cdot 5\end{array}$ & $\begin{array}{l}11 \cdot 0-40 \cdot 2 \\
17 \cdot 8-73 \cdot 3\end{array}$ & $\begin{array}{c}370 \\
1240^{\star}\end{array}$ & $\begin{array}{l}350-570 \\
670-1700\end{array}$ \\
\hline $\begin{array}{l}\text { Duodenum: } \\
\text { First part } \\
\text { Second part } \\
\text { Colon: }\end{array}$ & $\begin{array}{r}10 \cdot 2 \\
8 \cdot 7\end{array}$ & $\begin{array}{l}7 \cdot 3-12 \cdot 7 \\
4 \cdot 5-14 \cdot 5\end{array}$ & $\begin{array}{l}190 \\
170\end{array}$ & $\begin{array}{r}110-280 \\
70-210\end{array}$ \\
\hline $\begin{array}{l}\text { Ascending } \\
\text { Transverse } \\
\text { Descending } \\
\text { Sigmoid } \\
\text { Rectum }\end{array}$ & $\begin{array}{r}12 \cdot 9 \\
7 \cdot 7 \\
7 \cdot 7 \\
9 \cdot 7 \\
10 \cdot 7\end{array}$ & $\begin{array}{l}7 \cdot 1-13 \cdot 3 \\
6 \cdot 5-15 \cdot 7 \\
5 \cdot 7-13 \cdot 2 \\
7 \cdot 1-15 \cdot 5 \\
6 \cdot 7-12 \cdot 2\end{array}$ & $\begin{array}{l}230 \\
150 \\
150 \\
210 \\
170\end{array}$ & $\begin{array}{r}150-240 \\
90-480 \\
70-360 \\
110-430 \\
130-290\end{array}$ \\
\hline
\end{tabular}

Statistical analysis compares tissue concentrations between the antrum and the body of the stomach. ${ }^{\star} \mathrm{p}<0.01$. 
Figure 3: Rates of gastric secretion of pancreatic secretory trypsin inhibitor (PSTI) before and after stimulation with pentagastrin. The horizontal lines indicate the medians. ${ }^{\star} p<0.05$.
Figure 4: Effect of $p H$ on the stability of pancreatic secretory trypsin inhibitorlike immunoreactivity (PSTI-LI) in gastric juice. The results are a mean of two experiments.

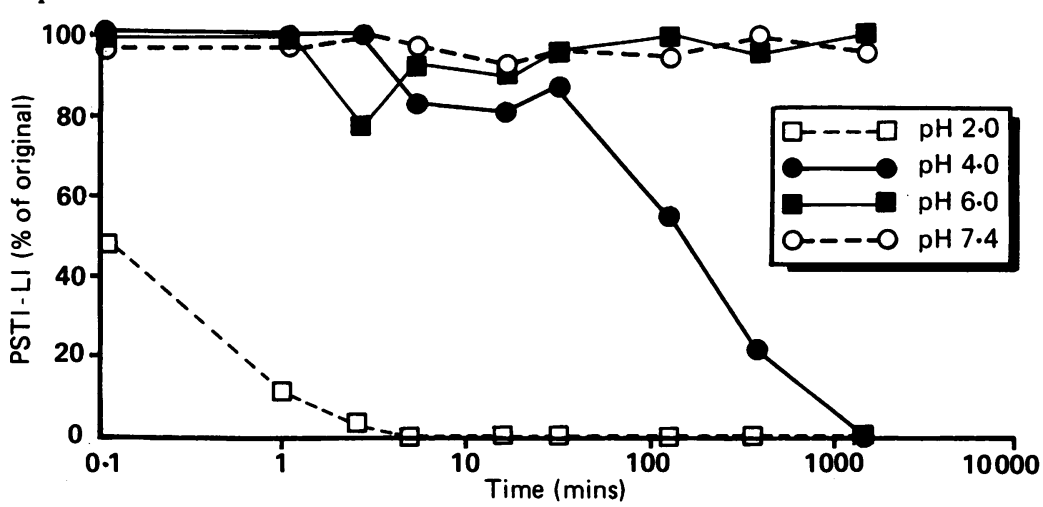

CHROMATOGRAPHY OF GASTROINTESTINAL PSTI-LI PSTI-LI in gastric juice, gastric mucosa, and colonic mucosa eluted from reversed phase high

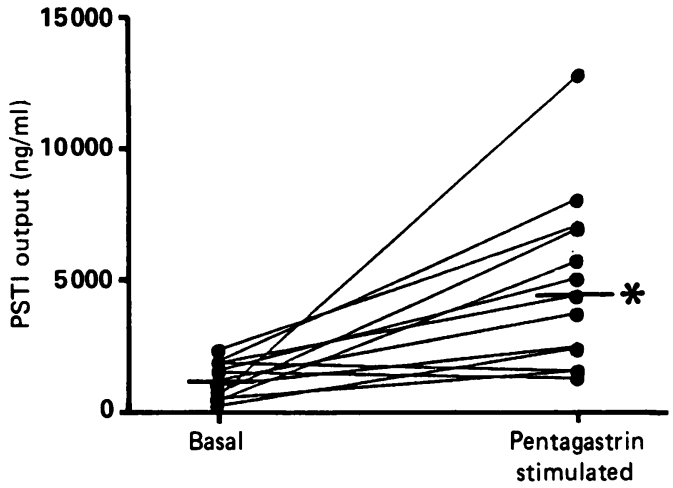

TABLE II Concentrations and secretion rates of pancreatic secretory trypsin inhibitor $(n=13)$ in basal and pentagastrin stimulated gastric juice

\begin{tabular}{lcc}
\hline $\begin{array}{l}\text { Concentration of } \\
P S T I-L I(\mu g / l):\end{array}$ & Median & Range \\
\hline Basal & 9 & $3-21$ \\
Stimulated & 12 & $3-21$ \\
Output of & & \\
$\quad$ PSTI-LI $(\mathrm{ng} / \mathrm{h}):$ & 1430 & $180-2810$ \\
$\quad$ Basal & $4500^{\star}$ & $1250-12770$ \\
Stimulated & & \\
\hline
\end{tabular}

${ }^{\star} \mathrm{p}<0.05 v$ basal.

of PSTI-LI in basal juice was not significantly changed during stimulation with pentagastrin (Table II). Because of the increase in the volume of juice secreted, however, the output of PSTILI rose significantly $(p<0.05)$ after stimulation with pentagastrin (Fig 3). PSTI-LI was labile in acidic gastric juice (Fig 4). The disappearance half times were less than 1 minute at $\mathrm{pH} 2 \cdot 0$, but about 2 hours at $\mathrm{pH} 4$. There was no detectable loss of PSTI in gastric juice at $\mathrm{pH} 6.0$ and 7.4 in 24 hours. There was no detectable loss of PSTI$\mathrm{LI}$ after incubation in Tris buffer at $\mathrm{pH} \mathrm{2.0}$ and 4.0 in the absence of gastric juice for 24 hours. After incubation of PSTI in unbuffered gastric juice, $\mathrm{pH} 1.4$ for 1 hour in the presence of pepstatin, $81 \%$ of original immunoreactivity remained. No PSTI-LI was detectable in the control tube without pepstatin.

PSTI IN PANCREATIC JUICE

The median (range) concentration of PSTI in pancreatic juice, as measured by radioimmunoassay, was $12 \cdot 4(8 \cdot 8-16 \cdot 0) \mathrm{mg} / \mathrm{l}$.

and antrum,PSTI-LI wasobserved in the foveolar cells lining the gastric pits (Fig 6A) but was absent in the superficial epithelial cells. In the duodenum intense PSTI-LI was observed in the Paneth cells (Fig 6B) but was absent in other cell types. In colonic mucosa the non mucus secreting cells of the colonic crypts were positive (Fig 6C) but the goblet cells were negative.

\section{Discussion}

In this study we determined the concentrations of PSTI-LI for the first time in fresh tissue obtained from the gastrointestinal tract at endoscopy. PSTI-LI was present in the stomach, 


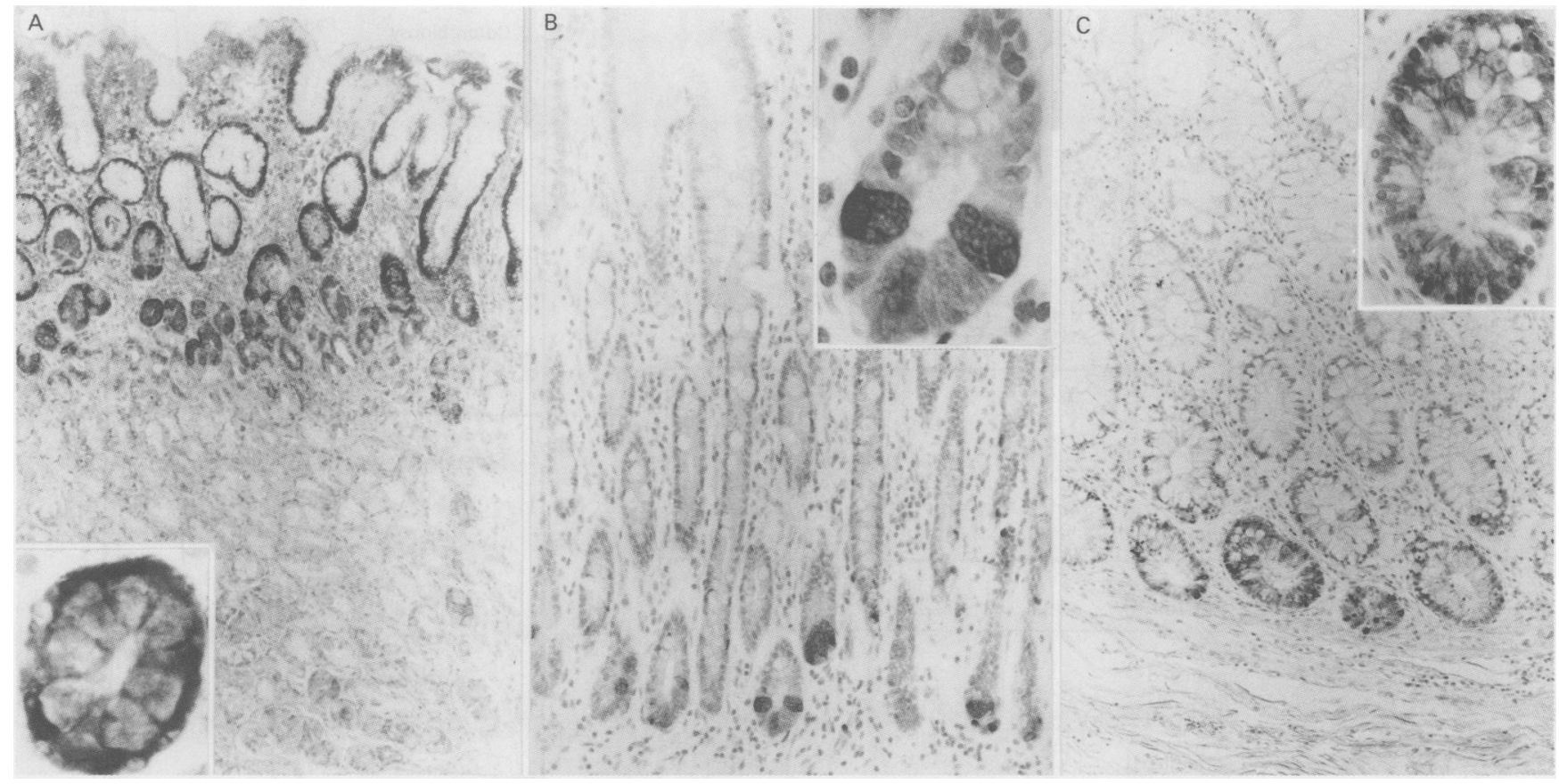

Figure 6: Paraffin sections of gastrointestinal mucosa stained with an indirect immunoperoxidase method using an anti-PSTI antibody, $(A)$ normal gastric mucosa (original magnification $\times 31 \cdot 5$, inset $\times 236$ ) showing foveolar cell positivity in gastric pits; $(B)$ normal duodenal mucosa (original magnification $\times 50$, inset $\times 193$ ) showing Paneth cell positivity; $(C)$ normal colonic mucosa (original magnification $\times 31 \cdot 5$, inset $\times 96$ ) showing non mucus cell positivity in colonic crypts.

duodenum, and colon but undetectable in the oesophagus. Tissue concentrations were greatest in the gastric antrum. PSTI-LI was found to be in a specific cell type in each region of the gut. We have shown for the first time that PSTI is secreted into the lumen of the stomach. PSTI is rapidly destroyed by acid pepsin but stable at the neutral $\mathrm{pH}$ found in the gastric mucus layer.

In a previous study Shibata et al measured PSTI-LI in cadaveric small intestine and surgically resected stomach, ${ }^{6}$ and found concentrations over an order of magnitude lower than in the present study. The lower concentrations that they reported may have been due to loss of PSTI through hydrolysis by mucosal enzymes before extraction and a higher proportion of submucosal tissues in samples.

The cellular distribution of gastrointestinal PSTI-LI reported in the present study is consistent with the main findings of two other groups. ${ }^{78}$ The weak PSTI-LI seen by others, however, in the goblet cells of the colon and in other gastric cell types, including chief cells, was not observed in the present study.

We are not aware of any previous report of the secretion of PSTI into gastric juice. The concentrations of PSTI-LI in gastric juice did not rise significantly during the infusion of pentagastrin, although there was a significant increase in the output of gastric PSTI. Pentagastrin has been reported to increase gastric secretion of carbohydrate from the same cell type in the cat. ${ }^{16}$

In the present study PSTI was shown to be rapidly destroyed by pepsin in gastric juice at acid $\mathrm{pH}$, but stable if the juice was neutralised. PSTI probably exerts its protective effect in the gastric mucus layer which is kept at a neutral $\mathrm{pH}$ due to gastric secretion of bicarbonate. ${ }^{17}$ Hydrolysis of PSTI by pepsin is probably responsible for the rapid loss of PSTI-LI in acidic extracts of gastric mucosa that was reported by Shibata et al. ${ }^{6}$
The results of the present analytical studies are consistent with the results of others who have shown that pancreatic PSTI exists in multiple forms. ${ }^{23}$ These differ chiefly in the degree of deamination of the asparagine residues which are unusually abundant in PSTI. Fraction $\mathrm{II}_{1}$ and $\mathrm{II}_{2}$ had the predicted mass of the molecule whereas fractions I and III had a molecular mass consistent with monodeaminated PSTI. In addition, Kikuchi et al found a form of PSTI in pancreatic juice which had five amino acids missing from the $\mathrm{N}$-terminal, which was not found here. ${ }^{2}$

The presence of PSTI in all regions of the gut, and its secretion into the lumen, suggest that PSTI may protect the whole gut from proteolytic enzymes. Gastric PSTI is presumably important during episodes of duodenogastric reflux which occur in health, ${ }^{18}$ occur more frequently in some diseases such as gastric ulcer, ${ }^{19}$ and occur more or less constantly after some forms of gastric surgery. ${ }^{19}$ Reflux of duodenal juice may raise intragastric $\mathrm{pH}$ to levels at which pancreatic enzymes are active but PSTI is stable. Concentrations of PSTI measured in pancreatic juice in the present study were similar to those reported by others ${ }^{3}$ and approximately 1000 times higher than concentrations found in gastric juice. Concentrations of PSTI in the gastric mucusbicarbonate layer, however, may be considerably higher than those found in the lumen of the stomach. In addition, the concentration of trypsin entering the mucus layer may be diminished by dilution and by peptic destruction of trypsin in the lumen of the stomach..$^{20}$ It is interesting that gastric mucosal PSTI is most abundant in the antrum, which is most exposed to refluxed enzymes. Colonic PSTI may protect the colonic epithelium from pancreatic enzymes which remain active in colonic contents. ${ }^{21}$ PSTI also inhibits elastase and chymotrypsin ${ }^{4}$ as well as trypsin.

Recent work has shown that PSTI is a growth 
facior as well as a protease inhibitor. We showed tisar human PSTI stimulates growth of AR4-2J cells derived from a rat pancreatic acinar cell tumolir..$^{2}$ Others have shown that human PSTI stimuiatis growth of human fibroblasts ${ }^{23}$ and human endothelial cells. ${ }^{24}$ The growth stimulating effert of PSTI may be a consequence of its sequence homology with epidermal growth factor." Paised intragastric PSTI concentrations could contribute to trophic effects seen in the prolonged absence of gastric acid. ${ }^{26}$

Gastroiniestinal PSTI may provide an important and hitherto unrecognised protective mecharism. Further studies are required to determine the isctors which control the secretion of gastrointestina! PSTI and its possible role in the control of gastrointestinal growth.

We thank tie Wellcome Trust for financial support; the Medical Revearci Council for funding RP as an MRC training fellow; and Revearch Council for funding RP as an MRC training fellow; and
Dr S Levi and Sister Francis-Reme and the nursing staff of the Dr S Levi and Sister Francis-Reme and the nursing staff of the
gastric clitic for help in the collection of biopsy samples and samplus of gastric juice.

1 Kazal LA, Spicer DS, Brahinsky RA. Isolation of a crystalline trypsin inhibitor-anticoagulant protein from the pancreas. f Am Chem Soc 1948; 70: 304-40.

2 Kikuchi N, Nagata K, Yoshida N, et al. The multiplicity of human pancreatic secretory trypsin inhibitor. $\mathcal{F}$ Biochem 1985; 98: 687-94.

3 Greene LJ, Pubols MH, Bartelt DC. Human pancreatic secretory trypsin inhibitor. Methods Enzymol 1976; 45: 813-25.

4 Pubols MH, Bartlet DC, Greene LJ. Trypsin inhibitor from human pancreas and pancreatic juice. $\mathcal{F}$ Biol Chem 1974; 249: $2235-42$.

5 Yamamoto T, Nakamura Y, Nishide T, et al. Molecular cloning and nucleotide sequence of human pancreatic secretory trypsin inhibitor (PSTI) cDNA. Biochem Biophys Res Commun 1985; 132: 605-12

6 Shibata T, Ogawa M, Takata N, et al. Distribution of pancreatic secretory trypsin inhibitor in various human tissues and its inactivation in the gastric mucosa. Res Commun Chem Path Pharmacol 1987; 55: 243-8.

7 Bohe M, Lindstrom CG, Ohlsson K. Varying occurrence of gastroduodenal immunoreactive pancreatic secretory gastroduodenal immunoreactive pancreatic
trypsin inhibitor. $\mathcal{F}$ Clin Pathol $1987 ; 40: 1345-8$.

8 Fukayama M, Hayashi Y, Koike M, et al. Immunohisto- chemical localization of pancreatic secretory trypsin inhibitor in fetal and adult pancreatic and extrapancreatic tissues. $\mathcal{F}$ Histochem Cytochem 1986; 34: 227-35.

9 Shibata T, Ogawa M, Matsuda K, et al. Purification and characterization of pancreatic secretory trypsin inhibitor in human gastric mucosa. Clin Chim Acta 1986; 159: 27-36.

10 Iwai K, Fukuoka SI, Fushiki T, et al. Purification and sequencing of a trypsin-sensitive cholecystokinin-releasin peptide from pancreatic juice. I Biol Chem 1987; 262: 8956-9.

11 Hunter W, Greenwood F. Preparation of iodine-131 labelled human growth hormone of high specific activity. Nature 1962; 194: 494-6.

12 Schacterle G, Pollack R. A simplified method for the quantitative assay of small amounts of protein in biological material. Anal Biochem 1973; 51: 654-5.

13 Walsh K. Trypsinogens and trypsins of various species. Methods Enzymol 1973; 19: 41-64.

14 Polak J, Van Noorden S. Immunocytochemistry: modern methods and applications. 2nd ed. Bristol: Wright, 1986.

15 Huang S, Minassian H, More J. Application of immunofluorescent staining on paraffin sections improved by trypsin digestion. Lab Invest 1976; 35: 383-90.

16 Vagne M, Perret G. Regulation of gastric mucus secretion. Scand F Gastroenterol 1976; 42: 63-74.

17 Flemstorm G. Gastric and duodenal mucosal bicarbonate secretion. In: Johnson L, Christensen J, Jackson M, secretion. In: Johnson L, Christensen J, Jackson M, 2. 2nd ed. New York: Raven Press, 1987.

18 Keane F, Dimgno E, Malagelda J. Duodenogastric reflux in humans. Its relationship to fasting introduodenal motility and gastric, pancreatic and biliary secretion. Gastroenterology 1981; 81: 726-31.

19 Donovan I. Gastroduodenal motility. In: Bouchier I, Allen R, Hodgson H, Keighley M. Textbook of gastroenterology. London: Baillière Tindall, 1984: 105-10.

20 DiMango EP, Malagelada JR, Go VLW, et al. Fate of orally ingested enzymes in pancreatic insufficiency. $N$ Engl f Med 1977; 296: 1318-22.

21 Spiro H. Clinical gastroenterology. 3rd ed. New York: Macmillan, 1983: 1173 .

22 Freeman TC, Curry B, Calam J, et al. Pancreatic secretory trypsin inhibitor (PSTI) stimulates growth of AR4-2J rat pancreatic carcinoma cells. Gut 1989; 30: A752.

23 Ogawa M, Tsushima T, Ohba Y, et al. Stimulation of DNA Ogawa $M$, Tsushima T, Ohba Y, et al. Stimulation of DNA
synthesis in human fibroblasts by human pancreatic secretory trypsin inhibitor. Res Commun Chem Pathol Pharmacol 1985; 50: 155-8.

24 McKeehan WL, Sakagami Y, Hoshi H, et al. Two apparen human endothelial cell growth factors from hepatoma cells are tumor-associated proteinase inhibitors. $\mathcal{F}$ Biol Chem 1986; 261: 5378-83.

25 Hunt LT, Barker WC, Dayhoff MO. Epidermal growth factor: internal duplication and probable relationship to pancreatic secretory trypsin inhibitor. Biochem Biophys Res Commun 1974; 60: 1020-8.

26 Penston J, Wormsley KG. Achlorhydria: hypergastrinaemia carcinoids - a flawed hypothesis? Gut 1987; 28: 488-505. 